\title{
Transcriptional Mechanisms of Drug Addiction
}

\author{
Eric J. Nestler \\ Fishberg Department of Neuroscience and Friedman Brain Institute, Mount Sinai School of Medicine, New York, USA
}

\begin{abstract}
Regulation of gene expression is considered a plausible mechanism of drug addiction given the stability of behavioral abnormalities that define an addicted state. Numerous transcription factors, proteins that bind to regulatory regions of specific genes and thereby control levels of their expression, have been implicated in the addiction process over the past decade or two. Here we review the growing evidence for the role played by several prominent transcription factors, including a Fos family protein ( $\triangle$ FosB), cAMP response element binding protein (CREB), and nuclear factor kappa B (NF $\kappa \mathrm{B})$, among several others, in drug addiction. As will be seen, each factor displays very different regulation by drugs of abuse within the brain's reward circuitry, and in turn mediates distinct aspects of the addiction phenotype. Current efforts are geared toward understanding the range of target genes through which these transcription factors produce their functional effects and the underlying molecular mechanisms involved. This work promises to reveal fundamentally new insight into the molecular basis of addiction, which will contribute to improved diagnostic tests and therapeutics for addictive disorders.
\end{abstract}

KEY WORDS: Transcription factors; Nucleus accumbens; Ventral tegmental area; Orbitofrontal cortex; Chromatin remodeling; Epigenetics.

\section{INTRODUCTION}

The study of transcriptional mechanisms of addiction is based on the hypothesis that regulation of gene expression is one important mechanism by which chronic exposure to a drug of abuse causes long-lasting changes in the brain that underlie the behavioral abnormalities that define a state of addiction. ${ }^{1,2)}$ A corollary of this hypothesis is that changes induced in the functioning of several neurotransmitter systems, and in the morphology of certain neuronal cell types in the brain, by chronic drug administration are mediated in part via changes in gene expression.

Of course, not all drug-induced neural and behavioral plasticity is mediated at the level of gene expression, as we know the crucial contributions of translational and posttranslational modifications and protein trafficking in addiction-related phenomena. On the other hand, regulation of gene expression is one central mechanism and likely to be particularly crucial for the life-long abnormalities that

Received: May 15, 2012 / Accepted: July 18, 2012

Address for correspondence: Eric J. Nestler, MD, PhD Fishberg Department of Neuroscience and Friedman Brain Institute, Mount Sinai School of Medicine, One Gustave L. Levy Place, Box 1065, New York 10029, USA

Tel: +1-212-659-5656, Fax: +1-212-659-8510

E-mail: eric.nestler@mssm.edu characterize addiction. Indeed, transcriptional regulation provides a template on top of which these other mechanisms operate.

Work over the past $\sim 15$ years has provided increasing evidence for a role of gene expression in drug addiction, as several transcription factors - proteins that bind to specific responses elements in the promoter regions of target genes and regulate those genes' expression - have been implicated in drug action. According to this scheme, shown in Fig. 1, drugs of abuse, via their initial actions at the synapse, produce changes within neurons that signal to the nucleus and regulate the activity of numerous transcription factors and many other types of transcriptional regulatory proteins. ${ }^{3)}$ A These nuclear changes gradually and progressively build with repeated drug exposure and underlie stable changes in the expression of specific target genes which, in turn, contribute to the lasting changes in neural function that maintain a state of addiction. ${ }^{1,4)}$

This review focuses on several transcription factors, which have been shown to play important roles in addiction. We focus further on drug-regulated transcription factors within the brain's reward circuitry, areas of brain that normally regulate an individual's responses to natural rewards (e.g., food, sex, social interaction), but are corrupted by chronic drug exposure to cause addiction. This brain reward circuitry includes dopaminergic neu-

(c) This is an Open-Access article distributed under the terms of the Creative Commons Attribution Non-Commercial License (http://creativecommons.org/licenses/by-nc/3.0) which permits unrestricted non-commercial use, distribution, and reproduction in any medium, provided the original work is properly cited. 


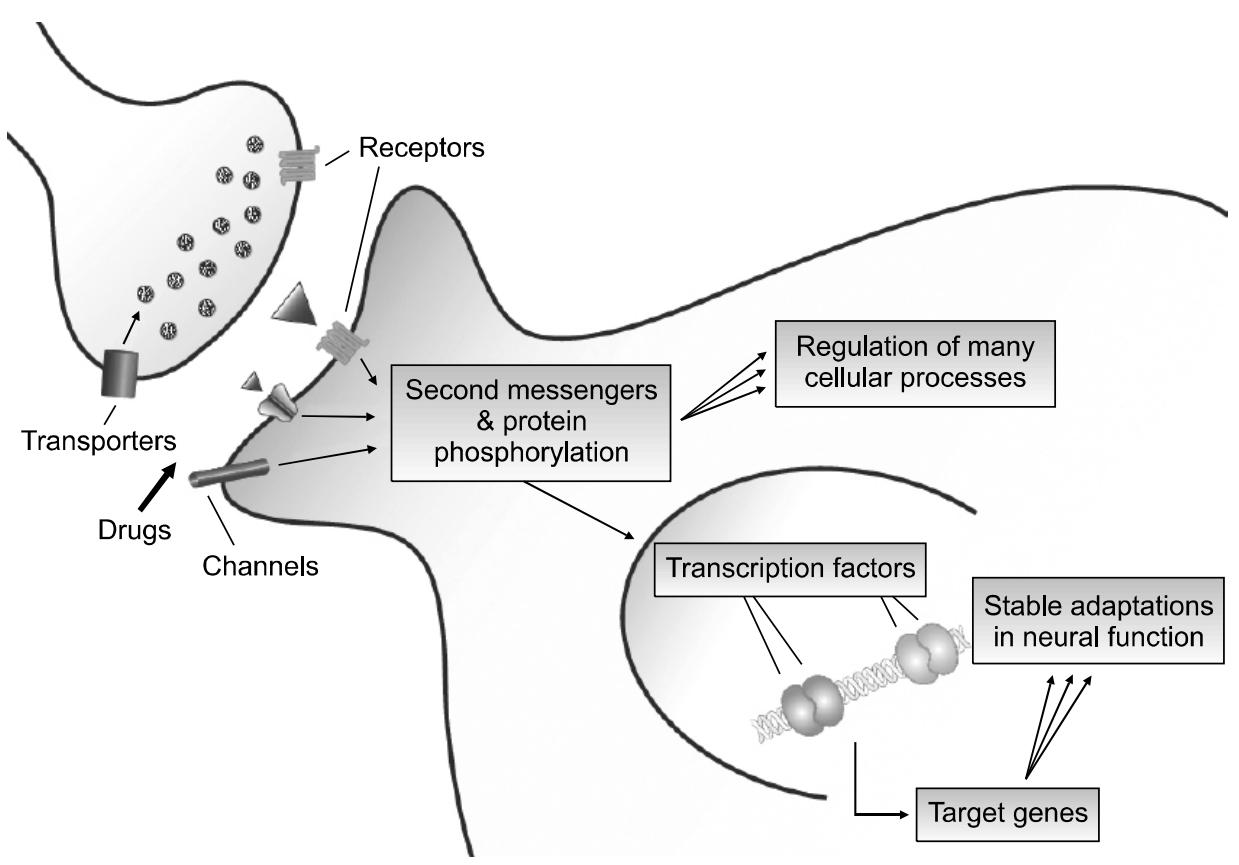

Fig. 1. Transcriptional actions of drugs of abuse. Although drugs of abuse act initially on their immediate protein targets at the synapse, their long-term functional effects are mediated in part via regulation of downstream signaling pathways which convertge on the cell nucleus. Here, drug regulation of transfactors leads to the stable regulation of specific target genes and to the lasting behavioral abnormalities that characterize addiction. rons in the ventral tegmental area of the midbrain and the several regions of limbic forebrain they innervate, including nucleus accumbens (ventral striatum), prefrontal cortex, amygdala, and hippocampus, among others. As will be seen, the vast majority of research on transcriptional mechanisms of addiction to date has concentrated on the nucleus accumbens.

\section{$\triangle \mathrm{FosB}$}

$\triangle$ FosB is encoded by the Fos $B$ gene and shares homology with other Fos family transcription factors, which include c-Fos, FosB, Fra1, and Fra2. ${ }^{5)}$ These Fos family proteins heterodimerize with Jun family proteins (c-Jun, JunB, or JunD) to form active activator protein-1 (AP1) transcription factors that bind to AP1 sites present in the promoters of certain genes to regulate their transcription. These Fos family proteins are induced rapidly and transiently in specific brain regions after acute administration of many drugs of abuse (Fig. 2). ${ }^{2}$ These responses are seen most prominently in nucleus accumbens and dorsal striatum, but also seen in several other brain areas. ${ }^{6}$ All of these Fos family proteins, however, are highly unstable and return to basal levels within hours of drug administration.

Very different responses are seen after chronic administration of drugs of abuse (Fig. 2). Biochemically modified isoforms of $\Delta \mathrm{FosB}\left(\mathrm{M}_{\mathrm{r}} 35-37 \mathrm{kD}\right)$ accumulate within the same brain regions after repeated drug exposure, whereas all Fos family members show tolerance (that is, reduced induction compared with initial drug exposures). ${ }^{7-9)}$ Such accumulation of $\Delta$ FosB has been observed for virtually all drugs of abuse, although different drugs differ somewhat in the relative degree of induction seen in nucleus accumbens core vs. shell, dorsal striatum, and other brain regions. ${ }^{2,6)}$ At least for some drugs of abuse, induction of $\triangle \mathrm{FosB}$ appears selective for the dynorphin-containing subset of medium spiny neurons - those that predominantly express D1 dopamine receptors - within striatal regions. The $35-37 \mathrm{kD}$ isoforms of $\Delta \mathrm{FosB}$ dimerize predominantly with JunD to form an active and long-lasting AP-1 complex within these brain regions, ${ }^{7,10)}$ although there is some evidence from in vitro studies that $\Delta \mathrm{FosB}$ may form homodimers. ${ }^{11)}$ Drug induction of $\Delta \mathrm{FosB}$ in the nucleus accumbens seems to be a response to the pharmacological properties of the drug per se and not related to volitional drug intake, since animals that self-administer cocaine or receive yoked drug injections show equivalent induction of this transcription factor in this brain region. ${ }^{6}$ In contrast, $\Delta$ FosB induction in certain other regions, for example, orbitofrontal cortex, requires volitional drug administration. $^{12)}$

The $35-37 \mathrm{kD} \Delta$ FosB isoforms accumulate with chronic drug exposure due to their extraordinarily long halflives. $^{7-13)}$ As a result of its stability, the $\Delta$ FosB protein persists in neurons for at least several weeks after cessation of drug exposure. We now know that this stability is due to two factors: 1 ) the absence in $\Delta \mathrm{FosB}$ of two degron 
A
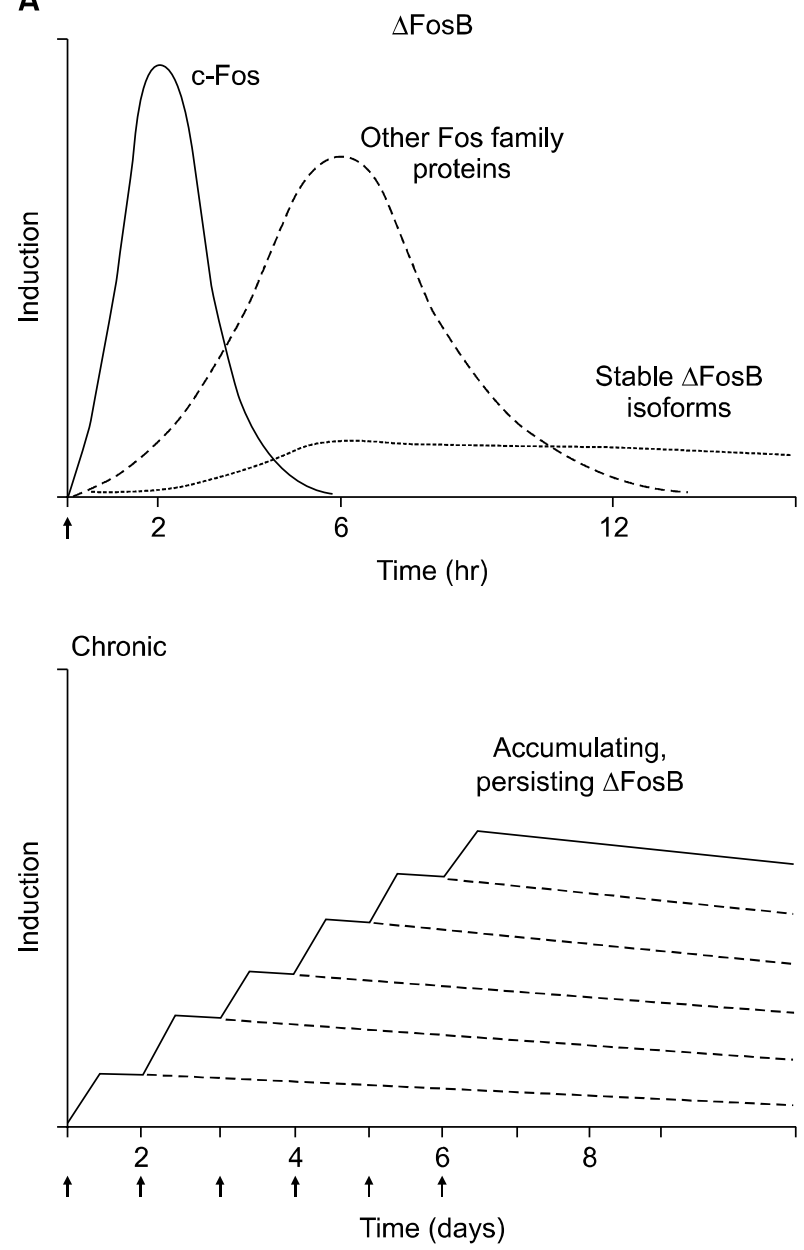

B
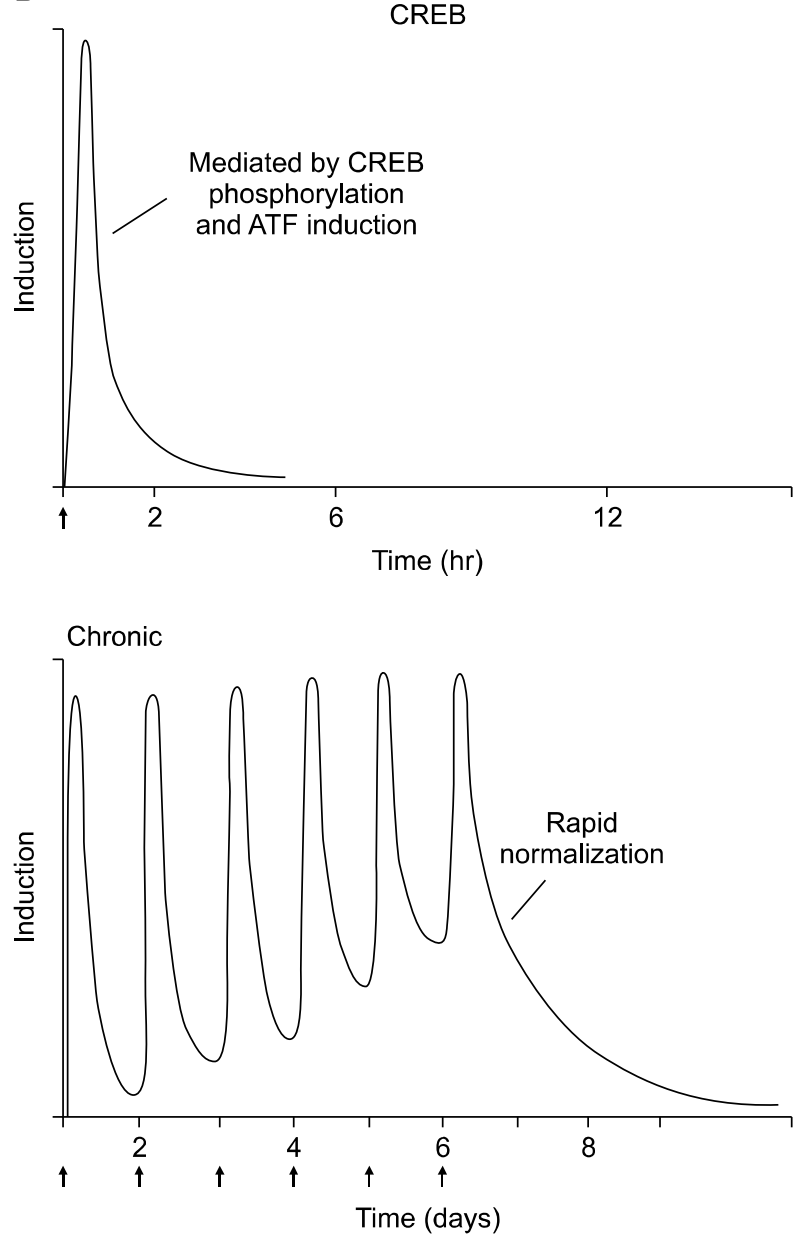

Fig. 2. Distinct temporal properties of drug regulation of $\triangle \mathrm{FosB}$ vs. CREB. (A) $\triangle \mathrm{FosB}$. The top graph shows several waves of Fos family proteins (comprised of C-Fos, FosB, $\triangle$ FosB (33 kD isoform), Fra1, Fra2) induced in nucleus accumbens by acute administration of a drug of abuse. Also induced are biochemically modified isoforms of $\triangle \mathrm{FosB}(35-37 \mathrm{kD})$; they are induced at low levels by acute drug administration, but persist in brain for long periods due to their stability. The lower graph shows that with repeated (e.g., twice daily) drug administration, each acute stimulus induces a low level of the stable $\triangle F$ FosB isoforms. This is indicated by the lower set of overlapping lines, which indicate $\Delta$ FosB induced by each acute stimulus. The result is a gradual increase in the total levels of $\Delta$ FosB with repeated stimuli during a course of chronic treatment. This is indicated by the increasing stepped line in the graph. (B) CREB. Activation of CRE transcriptional activity, mediated via phosphorylation and activation of CREB and possibly via the induction of certain ATFs, occurs rapidly and transiently in nucleus accumbens in response to acute drug administration. This "peak and trough" pattern of activation persists through chronic drug exposure, with CRE transcription levels reverting to normal within 1-2 days of drug withdrawal.

domains, which are present at the C-terminus of full length FosB and all other Fos family proteins and target those proteins to rapid degradation, and 2) the phosphorylation of $\Delta \mathrm{FosB}$ at its $\mathrm{N}$-terminus by casein kinase 2 and perhaps other protein kinases. ${ }^{1416)}$ The stability of the $\Delta$ FosB isoforms provides a novel molecular mechanism by which drug-induced changes in gene expression can persist despite relatively long periods of drug withdrawal. We have, therefore, proposed that $\Delta$ FosB functions as a sustained "molecular switch" that helps initiate and then maintain an addicted state. ${ }^{1,2)}$

\section{Role in Addiction}

Insight into the role of $\Delta \mathrm{FosB}$ in drug addiction has come largely from the study of bitransgenic mice in which $\Delta$ FosB can be induced selectively within the nucleus accumbens and dorsal striatum of adult animals. ${ }^{17)}$ Importantly, these mice overexpress $\Delta$ FosB selectively in the dynorphin-containing medium spiny neurons, where the drugs are believed to induce the protein. $\triangle$ FosB-overexpressing mice show augmented locomotor responses to cocaine after acute and chronic administration. ${ }^{17)}$ They also show enhanced sensitivity to the rewarding effects of cocaine and of morphine in place conditioning assays, ${ }^{17-19)}$ 
and self-administer lower doses of cocaine, and work harder for cocaine, than littermates that do not overexpress $\Delta$ FosB $^{20)}$ Additionally, $\Delta$ FosB overexpression in nucleus accumbens exaggerates the development of opiate physical dependence and promotes opiate analgesic tolerance. ${ }^{19)}$ In contrast, $\Delta$ FosB expressing mice are normal in several other behavioral domains, including spatial learning as assessed in the Morris water maze. ${ }^{17)}$ Specific targeting of $\Delta$ FosB overexpression to the nucleus accumbens, by use of viral-mediated gene transfer, has yielded equivalent data. ${ }^{19)}$

In contrast, targeting $\Delta \mathrm{FosB}$ expression to the enkepahlin-containing medium spiny neurons in nucleus accumbens and dorsal striatum (those that predominantly express D2 dopamine receptors) in different lines of bitransgenic mice fail to show most of these behavioral phenotypes. ${ }^{19)}$ In contrast to overexpression of $\Delta \mathrm{FosB}$, overexpression of a mutant Jun protein ( $\Delta$ cJun or $\Delta \mathrm{JunD}$ ) - which functions as a dominant negative antagonist of AP1 mediated transcription by use of bitransgenic mice or viral-mediated gene transfer, produces the opposite behavioral effects. ${ }^{18,19,21)}$ These data indicate that induction of $\Delta$ FosB in dynorphin-containing medium spiny neurons of the nucleus accumbens increases an animal's sensitivity to cocaine and other drugs of abuse, and may represent a mechanism for relatively prolonged sensitization to the drugs.

The role played by $\Delta$ FosB induction in other brain regions is less well understood. Recent studies have shown that $\Delta$ FosB induction in orbitofrontal cortex mediates tolerance to some of the cognitive-disrupting effects of acute cocaine exposure, which might serve to further promote drug intake. ${ }^{12,22)}$

\section{$\triangle$ FosB Target Genes}

Since $\Delta \mathrm{FosB}$ is a transcription factor, it presumably produces this interesting behavioral phenotype in nucleus accumbens by enhancing or repressing expression of other genes. Using our inducible, bitransgenic mice that overexpress $\Delta$ FosB or its dominant negative $\Delta$ cJun, and analyzing gene expression on Affymetrix chips, we demonstrated that - in the nucleus accumbens in vivo $-\Delta$ FosB functions primarily as a transcriptional activator, while it serves as a repressor for a smaller subset of genes. ${ }^{18)}$ This study also demonstrated the dominant role of $\Delta \mathrm{FosB}$ in mediating the genomic effects of cocaine: $\triangle$ FosB is implicated in close to one-quarter of all genes influenced in nucleus accumbens by chronic cocaine.

This genome-wide approach, along with studies of several candidate genes in parallel, have established several target genes of $\Delta \mathrm{FosB}$ that contribute to its behavioral phenotype. One candidate gene is GluA2, an AMPA glutamate receptor subunit, which is induced in nucleus accumbens by $\Delta$ FosB. ${ }^{17)}$ Since GluA2-containing AMPA channels have a lower overall conductance compared to AMPA channels that do not contain this subunit, the cocaine- and $\Delta$ FosB-mediated upregulation of GluA2 in nucleus accumbens could account, at least in part, for the reduced glutamatergic responses seen in these neurons after chronic drug exposure. ${ }^{23)}$

Another candidate target gene of $\Delta$ FosB in nucleus accumbens is the opioid peptide, dynorphin. Recall that $\Delta \mathrm{FosB}$ appears to be induced by drugs of abuse specifically in dynorphin-producing cells in this brain region. Drugs of abuse have complex effects on dynorphin expression, with increases or decreases seen depending on the treatment conditions used. We have shown that induction of $\Delta$ FosB represses dynorphin gene expression in nucleus accumbens. ${ }^{19)}$ Dynorphin is thought to activate қ opioid receptors on ventral tegment area (VTA) dopamine neurons and inhibit dopaminergic transmission and thereby downregulate reward mechanisms. ${ }^{24,25)}$ Hence, $\Delta$ FosB repression of dynorphin expression could contribute to the enhancement of reward mechanisms mediated by this transcription factor. There is now direct evidence supporting the involvement of dynorphin gene repression in $\Delta$ FosB's behavioral phenotype. ${ }^{19)}$

Still additional target genes have been identified. $\Delta$ FosB represses the $c$-Fos gene which helps create the molecular switch - from induction of several short-lived Fos family proteins after acute drug exposure to the predominant accumulation of $\Delta$ FosB after chronic drug exposure - cited earlier. ${ }^{9)}$ In contrast, cyclin-dependent kinase-5 (Cdk5) is induced in the nucleus accumbens by chronic cocaine, an effect that we have shown is mediated via $\Delta$ FosB. ${ }^{18,21,26)}$ Cdk5 is an important target of $\Delta$ FosB since its expression has been directly linked to increases in dendritic spine density of nucleus accumbens medium spiny neurons, ${ }^{27,28)}$ in the nucleus accumbens that are associated with chronic cocaine administration. ${ }^{29,30)}$ Indeed, $\Delta$ FosB induction has been shown more recently to be both necessary and sufficient for cocaine-induced dendritic spine growth. ${ }^{31)}$

More recently, we have used chromatin immunoprecipitation (ChIP) followed by promoter chip (ChIP-chip) or by deep sequencing (ChIP-seq) to further identify $\Delta \mathrm{FosB}$ target genes. ${ }^{32)}$ These studies, along with the DNA expression arrays cited earlier, are providing a rich list of many additional genes that may be targeted - directly or indirectly - by $\Delta$ FosB. Among these genes are additional neurotransmitter receptors, proteins involved in pre- and postsynaptic func- 
tion, many types of ion channels and intracellular signaling proteins, proteins that regulate the neuronal cytoskeleton and cell growth, and numerous proteins that regulate chromatin structure. ${ }^{18,32)}$ Further work is needed to confirm each of these numerous proteins as bona fide targets of cocaine acting through $\Delta$ FosB and to establish the precise role that each protein plays in mediating the complex neural and behavioral aspects of cocaine action.

\section{CREB}

Cyclic AMP response element binding protein (CREB) is one of the most studied transcription factors in neuroscience and has been implicated in diverse aspects of neural plasticity. ${ }^{33)}$ It forms homodimers that can bind to genes at cyclic AMP response elements (CREs), but primarily activates transcription after it has been phosphorylated at Ser133 (by any of several protein kinases), which allows recruitment of CREB-binding protein (CBP) that then promotes transcription. The mechanism by which CREB activation represses the expression of certain genes is less well understood.

Both psychostimulants (cocaine and amphetamine) and opiates increase CREB activity, acutely and chronically as measured by increased phospho-CREB (pCREB) or reporter gene activity in CRE-LacZ transgenic mice - in multiple brain regions, including the nucleus accumbens and dorsal striatum. ${ }^{34-36)}$ The time course of this activation is very different from that exhibited by $\Delta$ FosB. As depicted in Fig. 2, CREB activation is highly transient in response to acute drug administration and reverts to normal levels within a day or two after withdrawal. In addition, CREB activation occurs in both the dynorphin and enkephalin subtypes of medium spiny neurons. ${ }^{34)}$ In contrast to cocaine and opiates, CREB shows more complicated and varied responses to other drugs of abuse. ${ }^{4)}$

Experiments involving the inducible overexpression of CREB or a dominant negative mutant in bitransgenic mice or with viral vectors have shown that activation of CREB - in striking contrast to $\triangle \mathrm{FosB}$ - in the nucleus accumbens decreases the rewarding effects of cocaine and of opiates as assessed in place conditioning assays. ${ }^{37,38)}$ Nevertheless, CREB activation, like $\triangle$ FosB induction, promotes drug self-administration. ${ }^{39)}$ Importantly, effects with dominant negative CREB have been validated with inducible knockdowns of endogenous CREB activity. ${ }^{39-41)}$ It is interesting that both transcription factors drive volitional drug intake; presumably $\Delta$ FosB does so via positive reinforcement, whereas CREB induces this phenotype via negative reinforcement. The latter possibility is consistent with considerable evidence that CREB activity in this brain region causes a negative emotional state. ${ }^{34,42)}$

CREB activity has been directly linked to the functional activity of nucleus accumbens medium spiny neurons. CREB overexpression increases, whereas dominant-negative CREB decreases, the electrical excitability of medium spiny neurons. ${ }^{43)}$ Possible differences between dynorphin and enkephalin neurons have not yet been explored. The observation that viral-mediated overexpression of a $\mathrm{K}^{+}$channel subunit in the nucleus accumbens, which decreases medium spiny neuron excitability, enhances locomotor responses to cocaine suggests that CREB acts as a break on behavioral sensitization to cocaine by upregulating neuron excitability. ${ }^{43)}$

Drugs of abuse activate CREB in several brain regions beyond the nucleus accumbens. One example is the ventral tegmental area, where chronic administration of cocaine or opiates activates CREB within dopaminergic and non-dopaminergic neurons. This effect seems to promote or attenuate the rewarding responses of drugs of abuse depending on the subregion of the ventral tegmental area affected.

Numerous target genes for CREB have been identified, through both open-ended and candidate gene approaches, which mediate these and other effects on nucleus accumbens medium spiny neurons and the resulting CREB behavioral phenotype. ${ }^{18,32,36)}$ Prominent examples include the opioid peptide dynorphin, ${ }^{37)}$ which feeds back and suppresses dopaminergic signaling to the nucleus accumbens as stated earlier. ${ }^{24,25)}$ Also implicated are certain glutamate receptor subunits, such as the GluA1 AMPA subunit and GluN2B NMDA subunit, as well as $\mathrm{K}^{+}$and $\mathrm{Na}^{+}$ion channel subunits, which together would be expected to control nucleus accumbens cell excitability. ${ }^{43,44)}$ BDNF is still another target gene for CREB in nucleus accumbens, and it too is implicated in mediating the CREB behavioral phenotype. ${ }^{35)}$ CREB induction also has been shown to contribute to cocaine's induction of dendritic spines on nucleus accumbens medium spiny neurons. ${ }^{45)}$

CREB is just one of several related proteins that bind CREs and regulate transcription of target genes. Several products of the cyclic AMP response element modulator (CREM) gene regulate CRE-mediated transcription. Some of the products (e.g., CREM) are transcriptional activators, whereas others (e.g., ICER or inducible cyclic AMP repressor) function as endogenous dominant negative antagonists. In addition, several activating transcription factors (ATFs) can influence gene expression in part by binding to CRE sites. Recent studies have implicated 
these various transcription factors in drug responses. Amphetamine induces ICER expression in nucleus accumbens, and overexpression of ICER in this region, by use of viral-mediated gene transfer, increases an animal's sensitivity to the behavioral effects of the drug. ${ }^{46)}$ This is consistent with findings, cited above, that local overexpression of dominant negative CREB mutants or local knockdown of CREB exerts similar effects. Amphetamine also induces ATF2, ATF3, and ATF4 in nucleus accumbens, while no effect is seen for ATF1 or CREM. ${ }^{47)}$ ATF2 overexpression in this region, like that of ICER, increases behavioral responses to amphetamine, while ATF3 or ATF4 overexpression has the opposite effect. Very little is known about the target genes for these various CREB family proteins, an important direction for future research.

\section{$\mathrm{NF} \kappa \mathrm{B}$}

Nuclear factor- $\kappa \mathrm{B}$ (NF $\kappa \mathrm{B})$, a transcription factor that is rapidly activated by diverse stimuli, is best studied for its role in inflammation and immune responses. It has more recently been shown to be important in synaptic plasticity and memory. ${ }^{48)} \mathrm{NF} \kappa \mathrm{B}$ is induced in the nucleus accumbens by repeated cocaine administration, ${ }^{49,50)}$ where it is required for cocaine's induction of dendritic spines of nucleus accumbens medium spiny neurons. Such induction of NF $\kappa \mathrm{B}$ contributes to sensitization to the rewarding effects of the drug. ${ }^{50)}$ A major goal of current research is to identify the target genes through which NF $\kappa \mathrm{B}$ causes this cellular and behavioral plasticity.

Interestingly, cocaine induction of $\mathrm{NF} \kappa \mathrm{B}$ is mediated via $\Delta$ FosB : $\triangle$ FosB overexpression in nucleus accumbens induces NF $\kappa \mathrm{B}$, while overexpression of the $\Delta \mathrm{cJun}$ dominant negative blocks cocaine induction of the transcription factor. $^{21,49)}$ Regulation of NF $\kappa$ B by $\Delta$ FosB illustrates the complex transcriptional cascades involved in drug action. As well, NF $\kappa \mathrm{B}$ has been implicated in some of the neurotoxic effects of methamphetamine in striatal regions. ${ }^{51)}$ The role of NF $\kappa \mathrm{B}$ in medium spiny neuron spinogenesis has recently been extended to stress and depression models, ${ }^{52)}$ a finding of particular importance considering the comorbidity of depression and addiction, and the well-studied phenomenon of stress-induced relapse to drug abuse.

\section{MEF2}

Myocyte enhancing factor-2 (MEF2) was discovered for its role in controlling cardiac myogenesis. More re- cently, MEF2 has been implicated in brain function. ${ }^{53)}$ Multiple MEF2 isoforms are expressed in brain, including in nucleus accumbens medium spiny neurons, where they form homo- and heterodimers that can activate or repress gene transcription depending on the nature of the proteins they recruit. Recent work outlines a possible mechanism by which chronic cocaine suppresses MEF2 activity in the nucleus accumbens in part through a D1 receptor-cAMP-dependent inhibition of calcineurin, a $\mathrm{Ca}^{2+}$-dependent protein phosphatase. ${ }^{28)}$ Cocaine regulation of Cdk5, which is also a target for cocaine and $\triangle F$ FosB as stated earlier, may be involved as well. This reduction in MEF2 activity is required for cocaine induction of dendritic spines on medium spiny neurons. An important focus of current work is to identify the target genes through MEF2 produces this effect.

\section{FUTURE DIRECTIONS}

The transcription factors discussed above are just a few of many that have been studied over the years in addiction models. Others implicated in addiction include the glucocorticoid receptor, nucleus accumbens 1 transcription factor (NAC1), early growth response factors (EGRs), and signal transducers and activators of transcription (STATs). ${ }^{1,2)}$ As just one example, the glucocorticoid receptor is required in dopaminoceptive neurons for cocaine seeking. ${ }^{54)}$ The goal of future research is to obtain a more complete view of the transcription factors induced in nucleus accumbens and other brain reward regions in response to chronic exposure to drugs of abuse and to define the range of target genes they influence to contribute to the behavioral phenotype of addiction.

The other major goal of future research is to delineate the precise molecular steps by which these various transcription factors regulate their target genes. Thus, we now know that transcription factors control gene expression by recruiting to their target genes a series of co-activator or co-repressor proteins which together regulate the structure of chromatin around the genes and the subsequent recruitment of the RNA polymerase II complex which catalyzes transcription. ${ }^{4}$ For example, recent research has demonstrated that the ability of $\Delta$ FosB to induce the cdk5 gene occurs in concert with the recruitment of a histone acetyltransferase and related chromatin remodeling proteins to the gene. ${ }^{55)}$ In contrast, the ability of $\Delta$ FosB to repress the c-Fos gene occurs in concert with the recruitment of a histone deacetylase and presumably several other repressive proteins such as a repressive histone methyltransferase (Fig. 3). ${ }^{2,9,31)}$ Given that hundreds of chroma- 
A Activation of the Cdk5 gene by $\Delta F o s B$

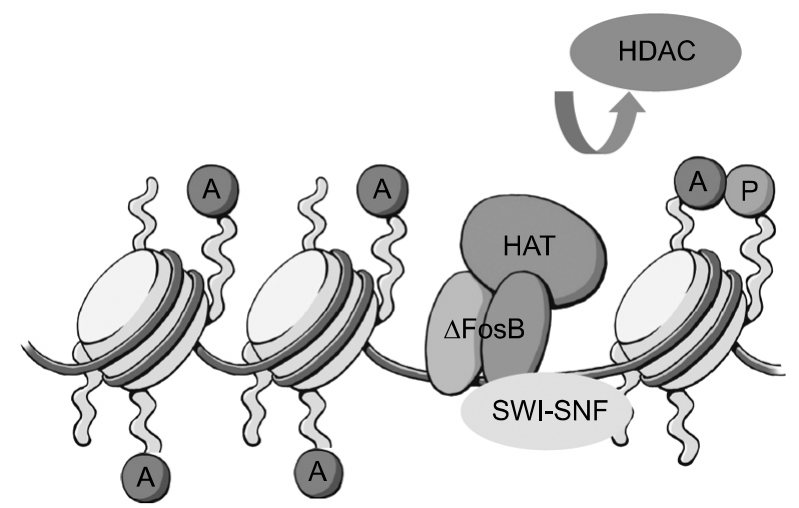

B

Repression of the c-Fos gene by $\Delta \mathrm{Fos} B$

HMT

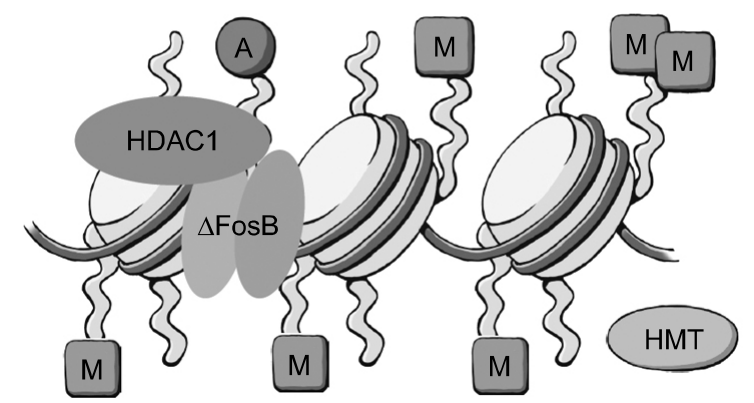

Fig. 3. Epigenetic mechanisms of $\Delta \mathrm{FosB}$ action. The figure illustrates the very different consequences when $\triangle \mathrm{FosB}$ binds to a gene that it activates (e.g., Cdk5) versus represses (e.g., c-Fos). At the Cdk5 promoter (A), $\triangle$ FosB recruits histone acetyltransferases (HAT) and chromatin remodeling proteins (e.g., SWI-SNF factors), which promote gene activation. There is also evidence for exclusion of histone deacetylases (HDAC). In contrast, at the c-Fos promoter (B), $\triangle$ FosB recruits HDACs as well as histone methytransferases (HMT), which repress gene expression. A, P, and M depict histone acetylation, phosphorylation, and methylation, respectively.

tin regulatory proteins are likely recruited to a gene in concert with its activation or repression, this work is just the tip of the iceberg of vast amounts of information that need to be discovered in the years ahead.

As progress is made in identifying target genes for drug-regulated transcription factors, this information will provide an increasingly complete template that can be used to guide drug discovery efforts. It is hoped that new medication treatments will be developed based on these dramatic advances in our understanding of transcription mechanisms that underlie addiction.

\section{REFERENCES}

1. Nestler EJ. Molecular basis of long-term plasticity underlying addiction. Nat Rev Neurosci 2001;2:119-128.
2. Nestler EJ. Review. Transcriptional mechanisms of addiction: role of delta FosB. Philos Trans $R$ Soc Lond B Biol Sci 2008;363:3245-3255.

3. Nestler EJ. Molecular neurobiology of addiction. Am $J$ Addict 2001;10:201-217.

4. Robison AJ, Nestler EJ. Transcriptional and epigenetic mechanisms of addiction. Nat Rev Neurosci 2011;12:623-637.

5. Morgan JI, Curran T. Immediate-early genes: ten years on. Trends Neurosci 1995; 18:66-67.

6. Perrotti LI, Weaver RR, Robison B, Renthal W, Maze I, Yazdani S, et al. Distinct patterns of DeltaFosB induction in brain by drugs of abuse. Synapse 2008;62:358-369.

7. Chen J, Kelz MB, Hope BT, Nakabeppu Y, Nestler EJ. Chronic Fos-related antigens: stable variants of deltaFosB induced in brain by chronic treatments. J Neurosci 1997;17: 4933-4941.

8. Hiroi N, Brown J, Haile C, Ye H, Greenberg ME, Nestler EJ. FosB mutant mice: loss of chronic cocaine induction of Fos-related proteins and heightened sensitivity to cocaine's psychomotor and rewarding effects. Proc Natl Acad Sci USA 1997;94:10397-10402.

9. Renthal W, Carle TL, Maze I, Covington HE 3rd, Truong HT, Alibhai I, et al. Delta FosB mediates epigenetic desensitization of the c-fos gene after chronic amphetamine exposure. J Neurosci 2008;28:7344-7349.

10. Hiroi N, Marek GJ, Brown JR, Ye H, Saudou F, Vaidya VA, et al. Essential role of the fosB gene in molecular, cellular, and behavioral actions of chronic electroconvulsive seizures. J Neurosci 1998;18:6952-6962.

11. Jorissen H, Ulery P, Henry L, Gourneni S, Nestler EJ, Rudenko G. Dimerization and DNA-binding properties of the transcription factor DeltaFosB. Biochemistry 2007;46:8360-8372.

12. Winstanley CA, LaPlant Q, Theobald DEH, Green TA, Bachtell RK, Perrotti LI, et al. DeltaFosB induction in orbitofrontal cortex mediates tolerance to cocaine-induced cognitive dysfunction. J Neurosci 2007;27:10497-10507.

13. Alibhai IN, Green TA, Potashkin JA, Nestler EJ. Regulation of fos $B$ and Deltafos $B$ mRNA expression: in vivo and in vitro studies. Brain Res 2007;1143:22-33.

14. Ulery PG, Rudenko G, Nestler EJ. Regulation of DeltaFosB stability by phosphorylation. J Neurosci 2006;26:5131-5142.

15. Ulery-Reynolds PG, Castillo MA, Vialou V, Russo SJ, Nestler EJ. Phosphorylation of DeltaFosB mediates its stability in vivo. Neuroscience 2009;158:369-372.

16. Carle TL, Ohnishi YN, Ohnishi YH, Alibhai IN, Wilkinson $\mathrm{MB}$, Kumar A, et al. Absence of conserved C-terminal degron domain contributes to $A F$ FosB's unique stability. Eur J Neurosci 2007;25:3009-3019.

17. Kelz MB, Chen J, Carlezon WA Jr, Whisler K, Gilden L, Beckmann AM, et al. Expression of the transcription factor deltaFosB in the brain controls sensitivity to cocaine. Nat 1999;401:272-276.

18. McClung CA, Nestler EJ. Regulation of gene expression and cocaine reward by CREB and DeltaFosB. Nat Neurosci 2003;6:1208-1215.

19. Zachariou V, Bolanos CA, Selley DE, Theobald D, Cassidy MP, Kelz MB, et al. DeltaFosB: An essential role for DeltaFos $B$ in the nucleus accumbens in morphine action. Nat Neurosci 2006;9:205-211.

20. Colby CR, Whisler K, Steffen C, Nestler EJ, Self DW. Striatal cell type-specific overexpression of DeltaFosB enhances incentive for cocaine. J Neurosci 2003;23:24882493.

21. Peakman MC, Colby C, Perrotti LI, Tekumalla P, Carle T, Ulery $\mathrm{P}$, et al. Inducible, brain region specific expression of 
a dominant negative mutant of c-Jun in transgenic mice decreases sensitivity to cocaine. Brain Res 2003;970:73-86.

22. Winstanley CA, Bachtell RK, Theobald DE, Laali S, Green TA, Kumar A, et al. Increased impulsivity during withdrawal from cocaine self-administration: role for DeltaFosB in the orbitofrontal cortex. Cereb Cortex 2009;19:435-444.

23. Kauer JA, Malenka RC. Synaptic plasticity and addiction. Nat Rev Neurosci 2007;8:844-858.

24. Shippenberg TS, Rea W. Sensitization to the behavioral effects of cocaine: modulation by dynorphin and kappaopioid receptor agonists. Pharmacol Biochem Behav 1997; 57:449-455.

25. Bruchas MR, Land BB, Chavkin C. The dynorphin/kappa opioid system as a modulator of stress-induced and proaddictive behaviors. Brain Res 2010;1314:44-55.

26. Bibb JA, Chen J, Taylor JR, Svenningsson P, Nishi A, Snyder GL, et al. Effects of chronic exposure to cocaine are regulated by the neuronal protein Cdk5. Nature 2001;410: 376-380.

27. Norrholm SD, Bibb JA, Nestler EJ, Ouimet CC, Taylor JR, Greengard P. Cocaine-induced proliferation of dendritic spines in nucleus accumbens is dependent on the activity of cyclin-dependent kinase-5. Neuroscience 2003;116:19-22.

28. Pulipparacharuvil S, Renthal W, Hale CF, Taniguchi M, Xiao G, Kumar A, et al. Cocaine regulates MEF2 to control synaptic and behavioral plasticity. Neuron 2008;59:621-633.

29. Robinson TE, Kolb B. Structural plasticity associated with exposure to drugs of abuse. Neuropharmacology 2004;47 (Suppl 1):33-46.

30. Russo SJ, Dietz DM, Dumitriu D, Morrison JH, Malenka $\mathrm{RC}$, Nestler EJ. The addicted synapse: mechanisms of synaptic and structural plasticity in nucleus accumbens. Trends Neurosci 2010;33:267-276.

31. Maze I, Covington HE 3rd, Dietz DM, LaPlant Q, Renthal $\mathrm{W}$, Russo SJ, et al. Essential role of the histone methyltransferase G9a in cocaine-induced plasticity. Science 2010; 327:213-216.

32. Renthal W, Kumar A, Xiao G, Wilkinson M, Covington HE 3rd, Maze I, et al. Genome-wide analysis of chromatin regulation by cocaine reveals a role for sirtuins. Neuron 2009;62:335-348.

33. Mayr B, Montminy M. Transcriptional regulation by the phosphorylation-dependent factor CREB. Nat Rev Mol Cell Biol 2001;2:599-609.

34. Carlezon WA Jr, Duman RS, Nestler EJ. The many faces of CREB. Trends Neurosci 2005;28:436-445.

35. Graham DL, Edwards S, Bachtell RK, DiLeone RJ, Rios M, Self DW. Dynamic BDNF activity in nucleus accumbens with cocaine use increases self-administration and relapse. Nat Neurosci 2007;10:1029-1037.

36. Briand LA, Blendy JA. Molecular and genetic substrates linking stress and addiction. Brain Res 2010;1314:219-234.

37. Carlezon WA Jr, Thome J, Olson VG, Lane-Ladd SB, Brodkin ES, Hiroi N, et al. Regulation of cocaine reward by CREB. Science 1998;282:2272-2275.

38. Barrot M, Olivier JD, Perrotti LI, DiLeone RJ, Berton O, Eisch AJ, et al. CREB activity in the nucleus accumbens shell controls gating of behavioral responses to emotional stimuli. Proc Natl Acad Sci U S A 2002;99:11435-11440.

39. Larson EB, Graham DL, Arzaga RR, Buzin N, Webb J, Green TA, et al. Overexpression of CREB in the nucleus accumbens shell increases cocaine reinforcement in selfadministering rats. J Neurosci 2011;31:16447-16457.

40. Green TA, Alibhai IN, Roybal CN, Winstanley CA, Theobald DE, Birnbaum SG, et al. Environmental enrich- ment produces a behavioral phenotype mediated by low cyclic adenosine monophosphate response element binding (CREB) activity in the nucleus accumbens. Biol Psychiatry 2010;67:28-35.

41. Vialou V, Feng J, Robison AJ, Ku SM, Ferguson D, Scobie $\mathrm{KN}$, et al. Serum response factor and cAMP response element binding protein are both required for cocaine induction of deltaFosB. J Neurosci 2012;32:7577-7584.

42. Dinieri JA, Nemeth CL, Parsegian A, Carle T, Gurevich VV, Gurevich E, et al. Altered sensitivity to rewarding and aversive drugs in mice with inducible disruption of cAMP response element-binding protein function within the nucleus accumbens. J Neurosci 2009;29:1855-1859.

43. Dong Y, Green T, Saal D, Marie H, Neve R, Nestler EJ, et al. CREB modulates excitability of nucleus accumbens neurons. Nat Neurosci 2006;9:475-477.

44. Huang YH, Lin Y, Brown TE, Han MH, Saal DB, Neve RL, et al. CREB modulates the functional output of nucleus accumbens neurons: a critical role of N-methyl-D-aspartate glutamate receptor (NMDAR) receptors. J Biol Chem 2008; 283:2751-2760.

45. Brown TE, Lee BR, Mu P, Ferguson D, Dietz D, Ohnishi YN, et al. A silent synapse-based mechanism for cocaine-induced locomotor sensitization. J Neurosci 2011;31:8163-8174.

46. Green TA, Alibhai IN, Hommel JD, DiLeone RJ, Kumar A, Theobald DE, et al. Induction of inducible cAMP early repressor expression in nucleus accumbens by stress or amphetamine increases behavioral responses to emotional stimuli. J Neurosci 2006;26:8235-8242.

47. Green TA, Alibhai IN, Unterberg S, Neve RL, Ghose S, Tamminga CA, et al. Induction of activating transcription factors (ATFs) ATF2, ATF3, and ATF4 in the nucleus accumbens and their regulation of emotional behavior. $J$ Neurosci 2008;28:2025-2032.

48. Meffert MK, Baltimore D. Physiological functions for brain NF-kappaB. Trends Neurosci 2005;28:37-43.

49. Ang E, Chen J, Zagouras P, Magna H, Holland J, Schaeffer $\mathrm{E}$, et al. Induction of nuclear factor-kappaB in nucleus accumbens by chronic cocaine administration. J Neurochem 2001;79:221-224.

50. Russo SJ, Wilkinson MB, Mazei-Robison MS, Dietz DM, Maze I, Krishnan V, et al. Nuclear factor kappa B signaling regulates neuronal morphology and cocaine reward. $J$ Neurosci 2009;29:3529-3537.

51. Asanuma M, Cadet JL. Methamphetamine-induced increase in striatal NF-kappaB DNA-binding activity is attenuated in superoxide dismutase transgenic mice. Brain Res Mol Brain Res 1998;60:305-309.

52. Christoffel DJ, Golden SA, Dumitriu D, Robison AJ, Janssen $W G$, Ahn $H F$, et al. I $\kappa B$ kinase regulates social defeat stress-induced synaptic and behavioral plasticity. $J$ Neurosci 2011;31:314-321.

53. Flavell SW, Kim TK, Gray JM, Harmin DA, Hemberg M, Hong EJ, et al. Genome-wide analysis of MEF2 transcriptional program reveals synaptic target genes and neuronal activity-dependent polyadenylation site selection. Neuron 2008;60:1022-1038.

54. Ambroggi F, Turiault M, Milet A, Deroche-Gamonet V, Parnaudeau S, Balado E, et al. Stress and addiction: glucocorticoid receptor in dopaminoceptive neurons facilitates cocaine seeking. Nat Neurosci 2009;12:247-249.

55. Kumar A, Choi KH, Renthal W, Tsankova NM, Theobald DE, Truong HT, et al. Chromatin remodeling is a key mechanism underlying cocaineinduced plasticity in striatum. Neuron 2005;48:303-314. 